\title{
ANALYSIS OF "STANDARD" (LIPICA) LIMESTONE TABLETS AND THEIR WEATHERING BY CARBONATE STAINING AND SEM IMAGING, A CASE STUDY ON THE VIS ISLAND, CROATIA
}

\author{
ANALIZA "STANDARDNIH" APNENČASTIH PLOŠČIC IZ \\ LIPIŠKEGA KAMNOLOMA Z BARVANJEM KARBONATOV IN \\ SLIKANJEM Z VRSTIČNIM ELEKTRONSKIM MIKROSKOPOM \\ V OKVIRU ŠTUDIJE KOROZIJE NA OTOKU VIS, HRVAŠKA
}

\author{
Kristina KRKLEC ${ }^{1}$, Tihomir MARJANAC ${ }^{2}$ \& Dražen PERICA ${ }^{3}$
}

\begin{abstract}
UDC 551.3.053:552.541(497.58)

Kristina Krklec, Tihomir Marjanac \& Dražen Perica: Analysis of "standard" (Lipica) lemestone tablets and their weathering by carbonate staining and SEM imaging, a case study on the Vis island, Croatia

This paper focuses on the evolution and patterns of microscale weathering forms and dissolution rates of "standard" (Lipica) limestone tablets. Analysis of carbonate weathering using combination of methods (quantitative analysis by the weight loss of "standard" tablets, and qualitative analysis of the weathered surfaces by stained acetate peels and SEM imaging) showed that dissolution takes place not only at the surface of limestone tablets, but also along voids and cavities in limestone tablets which makes total weathering surface larger than the area of the tablet surface. Dissolution is more pronounced on the micritic calcite surfaces (due to different dissolution kinetics of carbonate minerals), resulting in lowering of the surface (calcite matrix) which causes gradual unburial and removal of authigenic dolomite grains.

Keywords: limestone weathering, standard limestone tablets, acetate peels, SEM imaging.
\end{abstract}

\begin{abstract}
Izvleček
UDK 551.3.053:552.541(497.58)

Kristina Krklec, Tihomir Marjanac \& Dražen Perica: Analiza "standardnih" apnenčastih ploščic iz Lipiškega kamnoloma $z$ barvanjem karbonatov in slikanjem $z$ vrstičnim elektronskim mikroskopom v okviru študije korozije na otoku Vis, Hrvaška $\mathrm{V}$ članku obravnavamo razvoj mikro oblik in hitrost korozije pri preperevanju standardnih apnenčastih ploščic iz Lipiškega kamnoloma. Analiza temelji na konbinaciji meritve masnega primankljaja in kvalitativne analize SEM slik acetatnih lupin (peel) obarvanih preperelih površin. Raztapljanje je hitrejše na mikritnih kalcitnih površinah, kar povzroča njihovo relativno nižanje ter odstranitev avtogenih dolomitnih zrn, raztapljanje pa poteka poteka tudi v tako nastalih vdolbinicah.

Ključne besede: raztapljanje apnenca, standardne apnenčaste ploščice, acetatni piling, slikanje z SEMINTRODUCTION.
\end{abstract}

\section{INTRODUCTION}

In karst regions, weathering is one of fundamental phenomena in landscape evolution. Although weathering of limestones produces effects at a range of scales, it first manifests at microscopic level. Previous investigations of weathering of carbonate rocks at microscale were mainly focused on a) carbonate dissolution (Ford 1991), b) morphology (e.g. Viles \& Moses 1998) or c) evolution of carbonate rock surface roughness (Fornós et al. 2011), but the connection of microscale weathering forms and dissolution rates has not been studied previously.

\footnotetext{
${ }^{1}$ University of Zagreb, Faculty of Agriculture, Department of Soil Science, Svetošimunska 25, Zagreb, Croatia, e-mail:kkrklec@agr.hr; kristina.krklec@yahoo.com

${ }^{2}$ University of Zagreb, Faculty of Science, Department of Geology, Horvatovac 102a, Zagreb, Croatia, e-mail: marjanac@geol.pmf.hr

${ }^{3}$ University of Zadar, Department of Geography, Centre for karst and coast, P. Svačića 9, Zadar, Croatia, e-mail: dperica@unizd.hr

Received/Prejeto: 17.10 .2012
} 


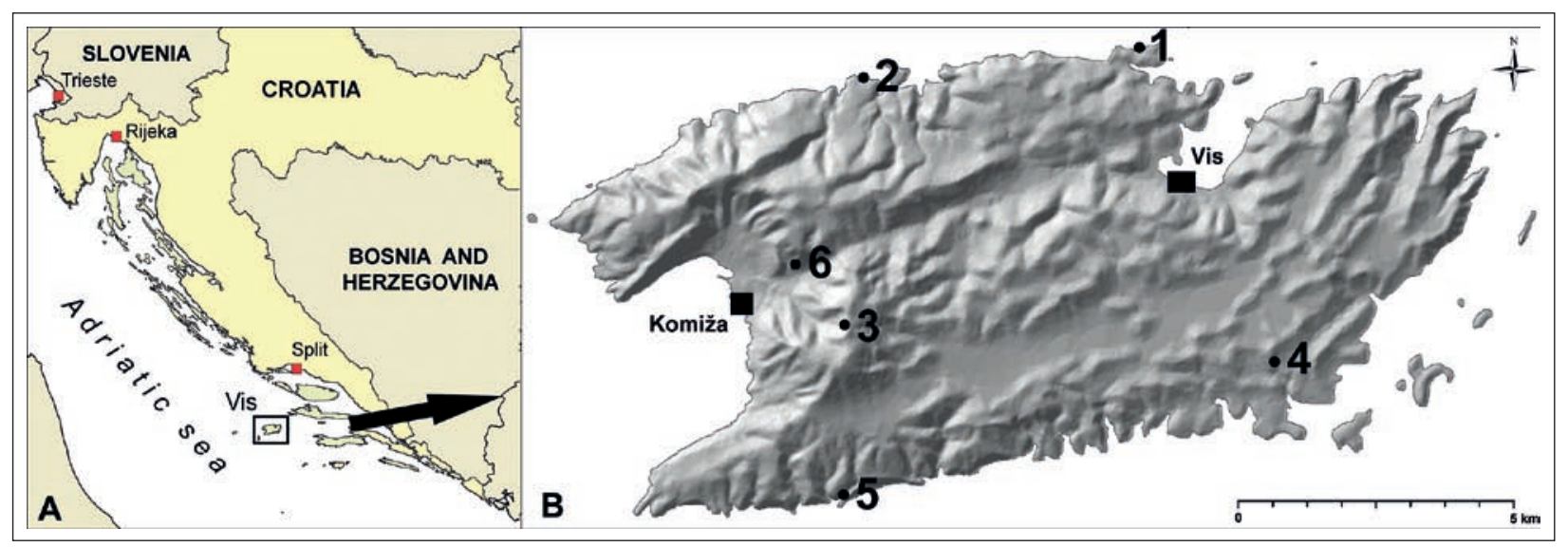

Fig. 1: Position of the Vis Island (A) and study locations (B).

This paper presents the analysis of limestone tablets weathering exposed at the surface during one-year experiment on the Vis Island, Croatia; by analysis of the weight loss of "standard" tablets, acetate peels, and Scanning Electron Microscope (SEM) imaging.

The Vis Island (Fig. 1) is characterised by three topographic ridges of ENE-WSW strike (Krklec et al. 2012a), built on Cretaceous carbonates and separated by two valleys filled with Quaternary deposits (terra rossa and sands). Petrographically different is the Komiža Bay which is formed in impermeable volcanic and clastic rocks of Triassic age (Borović et al. 1977; Koch \& Belak 2003; Belak et al. 2005; Bukovac \& Jamičić 2009), covered with breccias and conglomerates of Quaternary age (Palenik et al. 2005).

\section{MATHERIALS AND METHODS}

The intensity of rock dissolution on the Vis Island is measured at 6 locations (Fig. 1) by the "tablet method", first described by Gams (1959) (and later on used in many studies, e.g. Trudgill 1975, 1977; Matsukura \& Hirose 1999; Plan 2005) which essentially provides data on karstification intensity as a function of the weight loss of the experimental tablets during the time period considered.

The limestone tablets widely used to study the karstification intensity are from Lipica locality in Slovenia, and represent "standard" experimental tablets in order to compare the results obtained from various study sites. Six of these "standard" limestone tablets were exposed to environment under natural conditions for 1 year ( $8^{\text {th }}$ April 2009 to $8^{\text {th }}$ April 2010). The limestone tablets measuring $41 \mathrm{~mm}$ in diameter and $3-5 \mathrm{~mm}$ in thickness are cut from grey Senonian (Buser 1985) limestone borehole core from Lipica. On each limestone tablet, four holes $3 \mathrm{~mm}$ in diameter were drilled for fixing the tablet in the field.

This micritic to pelmicritic limestone contains 97.9$98.7 \% \mathrm{CaCO}_{3}, 0.21 \% \mathrm{MgO}$, less than $0.1 \% \mathrm{SiO}_{2}, 0.05 \%$
$\mathrm{Al}_{2} \mathrm{O}_{3}, 0.05 \% \mathrm{~S}, 0,007 \% \mathrm{Fe}_{2} \mathrm{O}_{3}$ (Gams 1985) and has density of $2.688 \mathrm{~g} / \mathrm{cm}^{3}$ (Prelovšek 2009; Krklec 2011).

The limestone tablets were prepared at the Department of Soil Science at the Faculty of Agriculture, University of Zagreb. These were pre-treated by staining of carbonates and production of the acetate peels (Katz \& Friedman 1965; Bouma 1969, Marjanac 1986), drying and weighing.

The procedure of carbonate staining comprised etching of limestone tablets for 10 seconds with $5 \% \mathrm{HCl}$, rinsing in distilled water, drying and treatment with alizarine red-S and potassium ferricyanide solutions. Staining of carbonates provides qualitative information on carbonate mineral phases, the colouring discriminating various carbonate minerals (Evamy \& Sherman 1962; Dickson 1966).

After staining and drying of limestone tablets, acetate peels were made on the stained surfaces in order to explore mineral composition of the limestone tablets and to enable monitoring of dissolution of individual mineral phases. The stained acetate peels were studied under optical microscope, and scanned as transparencies at $1200 \mathrm{dpi}$. 
Table 1. Locations characteristics.

\begin{tabular}{l|c|c|c|c|c}
\hline No. & $\begin{array}{c}\text { Altitude } \\
\text { a.s.l. }(\mathrm{m})\end{array}$ & $\begin{array}{c}\text { Slope } \\
\text { inclination }\left({ }^{\circ}\right)\end{array}$ & $\begin{array}{c}\text { Slope } \\
\text { exposition }\end{array}$ & Bedrock lithology and age & Vegetation cover \\
\hline 1 & 7 & 18.5 & $\mathrm{~N}$ & limestones, Turonian - Coniacian & maquis \\
\hline 2 & 97 & 16 & $\mathrm{~N}$ & limestones, Turonian - Coniacian & Holm oak forest and maquis \\
\hline 3 & 552 & vertical & SW & Limestones, Lower Cretaceous & Holm oak forest and maquis \\
\hline 4 & 97 & 20 & S & limestones, Turonian - Coniacian & garrigue and maquis \\
\hline 5 & 6 & 11 & SE & limestones, Turonian - Coniacian & garrigue and maquis \\
\hline 6 & 215 & 12 & SW & dolomites, Lower Cretaceous & garrigue and maquis \\
\hline
\end{tabular}

The tablets were then rinsed in distilled water, dried in laboratory oven for 24 hours at $50^{\circ} \mathrm{C}$ and weighted on an analytical scale with $0.0001 \mathrm{~g}$ precision. Every limestone tablet was weighted for three times in order to minimize errors. The calculated standard deviation of the weight was $0.0001 \mathrm{~g}$, which is within the analytical precision.

Weighting of limestone tablets immediately after their removal from the laboratory oven minimalized the possible influence of air moisture and possible weighing errors. After the investigation period, the tablets retrieved from the field were subjected to the same procedure. The surface area (A) was calculated for every limestone tablet using the following formula:

$$
A=\left[2 \pi r\left(r_{1}+H\right)\right]-8 \pi r^{2}+4\left(2 \pi r_{2} H\right)
$$

Where:

A - exposed surface $\left(\mathrm{cm}^{2}\right)$

$\mathrm{r}_{1}$ - radius of the limestone tablet $(\mathrm{cm})$

$\mathrm{r}_{2}$ - radius of the hole in limestone tablet $(\mathrm{cm})$

$\mathrm{H}-$ thickness of the limestone tablet $(\mathrm{cm})$

The prepared tablets were placed on the ground in horizontal position on selected locations on the Vis Island (Croatia) and exposed subaerially during one year ( ${ }^{\text {th }}$ April 2009 to $8^{\text {th }}$ April 2010). During that time the Vis Island had $1288.9 \mathrm{~mm}$ of rainfall and mean annual temperature of $16.5^{\circ} \mathrm{C}$ (Krklec et al. 2012b).

The difference in a tablet weight before and after the investigation period yielded the dissolution rate $(\mathrm{R})$ as calculated after the following formula (Plan 2005):

$$
R=\frac{\left(W_{1}-W_{2}\right)}{A \rho} 10^{4}
$$

Where:

$\mathrm{R}$ - dissolution rate $(\mu \mathrm{m} / \mathrm{yr})$

$\mathrm{W}_{1}-\mathrm{W}_{2}-$ loss of weight within one year $(\mathrm{g})$

$\rho$ - density of limestone tablets $\left(\mathrm{g} / \mathrm{cm}^{3}\right)$

A - area of the soluble surface $\left(\mathrm{cm}^{2}\right)$

The surface of retrieved tablets was studied by Scanning Electron Microscopy similar as in previous studies (e.g. Viles \& Moses 1998) at Ivan Rakovec Institute of Palaeontology of the Slovenian Academy of Sciences and Arts in Ljubljana, in order to identify the weathering patterns. The tablets were coated with gold and examined under magnifications 3,500-20,000 X using JEOL JSMT330A SEM.

On selected locations (Fig. 1, Tab. 1) prepared tablets were placed on the ground in horizontal position and fixed with plastic isolated wire, in order to avoid possible interactions of wire and limestone tablet (which could possibly affect the dissolution rate). In previous investigations of weathering of carbonate rocks using limestone tablets in this area (Gams 1985, Pahernik 1998), the tablets were fixed $100-150 \mathrm{~cm}$ above the ground, while we placed them on the ground in order to obtain more accurate dissolution rate. The limestone tablets $100-150 \mathrm{~cm}$ above ground are exposed only to rainfall, unlike the tablets on the ground surface which were exposed also to the rain which drained from upper parts of the slope, as well as to secondary moisture sources such as mist, dew and fog. These secondary moisture sources (although not measured in the present study) are essential inputs for wetting the tablets, and certainly contribute to total dissolution.

\section{RESULTS AND DISCUSSION}

The examination of the acetate peels prepared prior to exposure in the field revealed composition and microstructure of the limestone tablets. This fossiliferous, micritic to pelmicritic limestone is composed of $99 \%$ of calcite, and $1 \%$ of authigenic dolomite grains (hypidiomorphic to idiomorphic, rhomboedric). The share of 


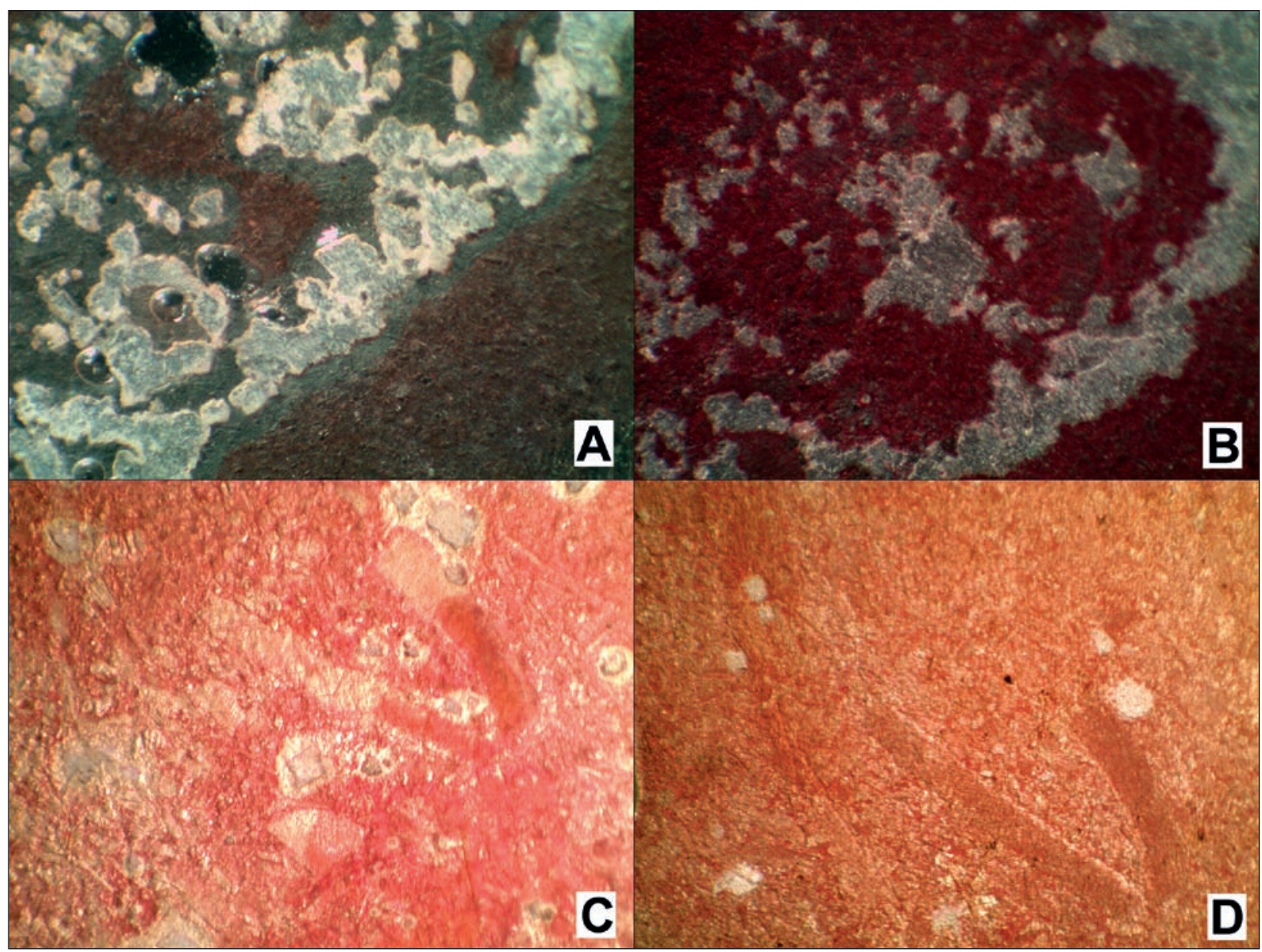

Fig. 2: Microphotographs of a tablet surface, stained acetate peels. Red, purple $=$ calcite; pink, white $=$ dolomite. $A$ and $C-$ before, $B$ and $D$ - after the field (subsoil) exposure. Note the dissolution effects (B) and complete removal (D) of dolomite grains.

fossil remains (bivalves) is $1 \%$, and the shells are made of calcite.

By examination of the acetate peels prepared prior to and after exposure in the field, the dissolution of limestone tablets was determined (Fig. 2), and revealed partial dissolution or complete disappearance of the dolomite grains (white to grey coloured in the stained peels).

This partial dissolution or removal of dolomite grains is also apparent on SEM images (Fig. 3). Here we can see that dolomite crystals protrude from the micritic calcite matrix (Figs. $3 \mathrm{~A}$ and C), but also that crystals are rimmed by a cavity (Figs. $3 \mathrm{~B}$ and $\mathrm{D}$ ) which makes them prone to removal from the rest of the rock when the matrix reaches threshold weathering, and eventually may be washed away leaving the empty cavity at their position (Figs. $3 \mathrm{E}$ and F). Dissolution of limestone tablets is more pronounced on the surfaces made of micritic calcite (resulting in high negative relief of the limestone tablets, Fig. $3 \mathrm{~A}$ and C) due to different dissolution kinetics of carbonate minerals (calcite dissolves faster than dolomite) (Morse \& Arvidson 2002; Liu et al. 2005). The dissolution takes place not only at the surface of the limestone tablets, but also along voids and cavities in limestone tablets (Fig. 2 B and D, Fig. 3 F). The cavities which rim the dolomite crystals were probably formed during late diagenetic growth of the dolomite crystals since the volume of dolomite elementary cell is smaller then that of calcite, and contribute to the rock's secondary porosity. Preferential weathering of calcitic matrix in relation to the dolomite crystals makes the later to loose cohesion in the rock which allows their easy detachment and removal (Fig. 4, 3 E). It should also be noted that in gross weight loss during the experimental exposure, two components contribute; a) the weight of dissolved calcite matrix, and b) the weight of mechanically removed dolomite crystals.

The differences in weight of the limestone tablets and calculated dissolution rates after year-long surface exposure are shown in Table 2, and calculated dissolution rates vary from 1.54 to $3.83 \mu \mathrm{m} / \mathrm{yr}$. 


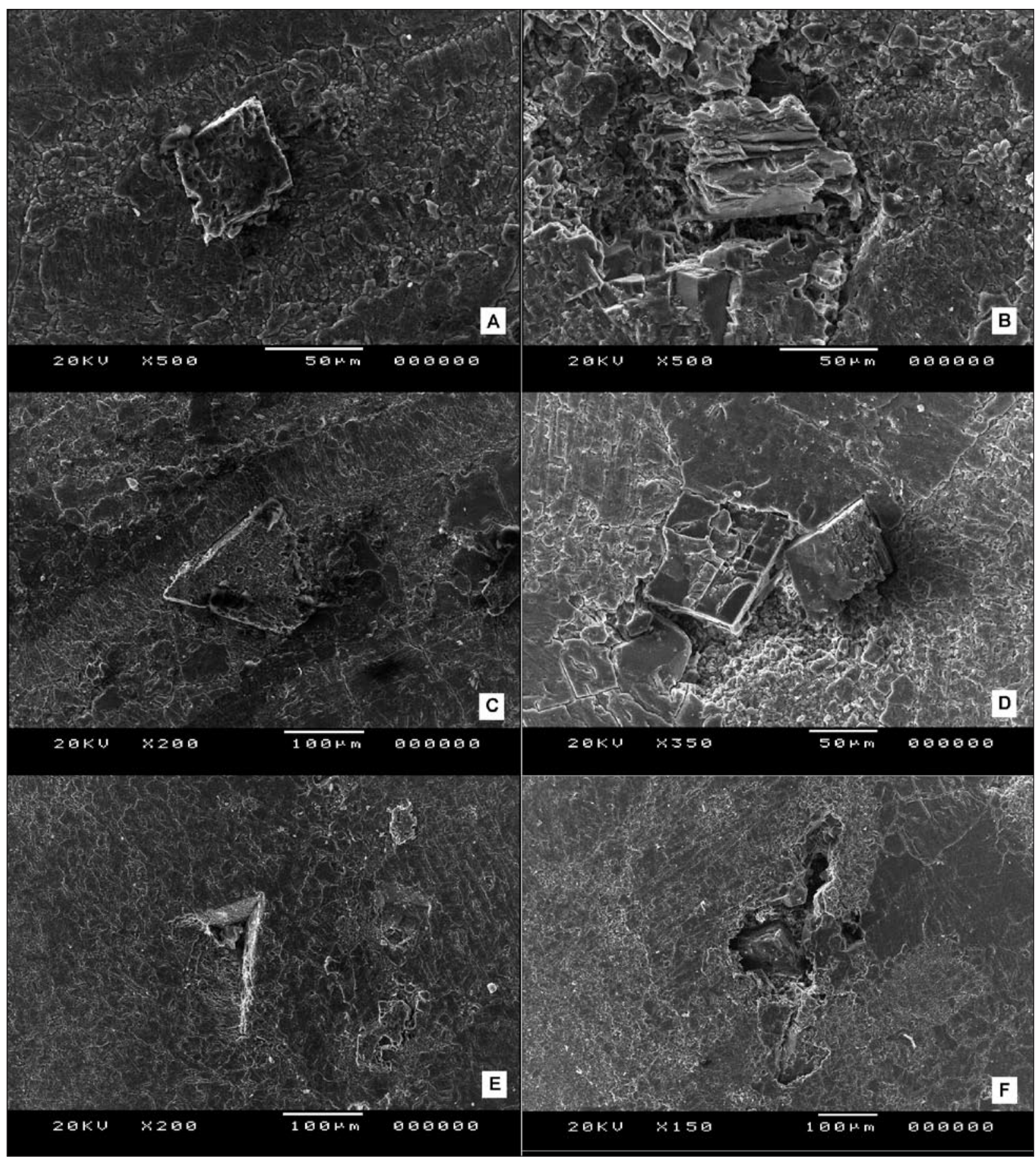

Fig. 3: SEM images of the-limestone tablets surface; A) idiomorphic dolomite grain in calcite matrix; B) cavities along a dolomite grain; C) hypidiomorphic dolomite grain in calcite matrix; D) cavities on contacts between calcite matrix and dolomite grain; E) mold/cavity left by removal of a dolomite grain; F) void in a limestone tablet, dolomite crystal barely visible in the cavity.

The data in Table 2 show that the highest calculated dissolution rates (higher than $3.5 \mu \mathrm{m} / \mathrm{yr}$ ) are measured at localities 1,2 and 6, and the lowest (lower than $2 \mu \mathrm{m} / \mathrm{yr}$ ) are measured at localities 4 and 5 . The localities 1 and 2 are located at the northern coast of the Vis Is- land, whereas localities 4 and 5 are at the southern coast (Fig. 1). The locality 6 is located above the west-facing Komiža Bay, 215 m a.s.l.

There is not statistically significant relationship between dissolution rate and altitude ( $\mathrm{p}$-value $=0.4760$, 


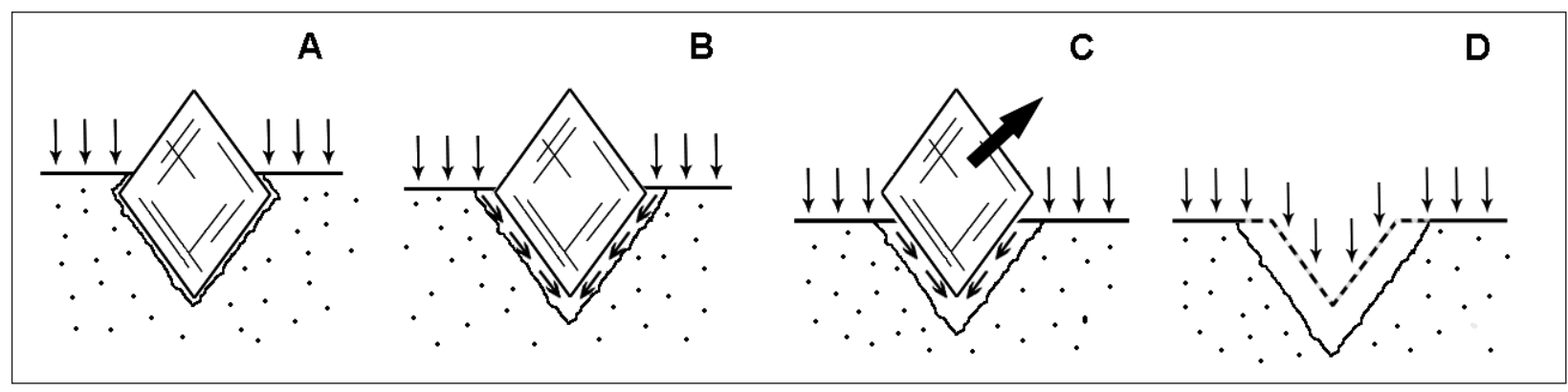

Fig. 4: Removal of dolomite grains is facilitated by lowering of the calcite surface, and dissolutional enlargement of the void which rims the dolomite crystal(s).

$\left.\mathrm{r}^{2}=1.765 \%\right)$, nor between dissolution rate and slope inclination $\left(\mathrm{p}\right.$-value $\left.=0.1507, \mathrm{r}^{2}=0.0343 \%\right)$.

The average of the higher dissolution rate sites $(1,2$ and 6) is $3.69 \mu \mathrm{m} / \mathrm{yr}$, and the average of the lower dissolution rate sites ( 4 and 5 ) is $1.66 \mu \mathrm{m} / \mathrm{yr}$. The difference in dissolution rate between higher and lower average values is $222 \%$. This difference can be attributed to the variations in the island climate, notably to the northern and eastern wind (Bora) which was most dominant wind during the investigation period. Bora is cold and dry wind which blows from the mainland seaward, but when passing over the water surfaces it uptakes moisture that and disperses it into water droplets. These sea water droplets are wetting the windward-coasts of the eastern Adriatic islands, as well as the northern coast of the Vis Island. This increased moisture contributes to enhanced dissolution of exposed carbonate rocks. The difference in dissolution rate between the localities 1 and 2 is $3.8 \%$,
Table 2: Weight of the limestone tablets before $\left(W_{1}\right)$ and after the exposure $\left(W_{2}\right)$, weight loss $\left(W_{1}-W_{2}\right)$ and calculated dissolution rates. The exposure was 364 days long and numbers of tablets (No) correspond to study localities shown in Fig. 1.

\begin{tabular}{l|l|l|l|l}
\hline No. & $W_{1}(g)$ & $W_{2}(g)$ & $W_{1}-W_{2}(g)$ & $R(\mu \mathrm{m} / \mathrm{yr})$ \\
\hline 1 & 13.4951 & 13.4645 & 0.0306 & 3.69 \\
\hline 2 & 13.7382 & 13.7064 & 0.0318 & 3.83 \\
\hline 3 & 12.0311 & 12.0076 & 0.0235 & 2.90 \\
\hline 4 & 13.9922 & 13.9774 & 0.0148 & 1.78 \\
\hline 5 & 13.5063 & 13.4932 & 0.0131 & 1.54 \\
\hline 6 & 14.1190 & 14.0894 & 0.0296 & 3.56 \\
\hline
\end{tabular}

and between the localities 4 and 5 is $13.5 \%$. These small variations in calculated dissolution rates for the localities at the same coast are probably caused by micro-climatic differences between the localities.

\section{CONCLUSION}

The analysis of carbonate weathering using a combination of methods (quantitative analysis by the weight loss of "standard" tablets, and qualitative analysis of the weathered surfaces by stained acetate peels and SEM imaging) is a good approach to investigate evolution and patterns of microscale weathering forms and dissolution rates. The obtained data show that dissolution takes place not only at the surface of limestone tablets, but also along voids and cavities in limestone tablets which makes total weathering surface larger than the area of the tablet surface. Due to different dissolution kinetics of carbonate minerals, the dissolution is more pronounced on the mic- ritic calcite surfaces resulting in an enhanced lowering of these material surfaces which cause gradual unburial and removal of dolomite grains. The measured weight loss is thus the result of the dissolved calcite and removed dolomite crystals. The measured dissolution rates suggest significant micro-climate dependence as indicated by the difference between northern and southern Vis coast dissolution rates. Therefore, further research in this topic should address a selection of sites covering wider microclimate variability, particularly locations with substantial difference in precipitation. 


\section{ACKNOWLEDGMENTS}

This research is a part of the research projects "Croatian coastal karst - geomorphological and ecological features" (269-2693084-3083) and 119-000000-1164 funded by the Ministry of science, education and sports, of the Republic of Croatia. The SEM study was supported by the grant provided by University of Zagreb, Faculty of Agriculture, which allowed Kristina Krklec to spend a part of the re- search time in Ljubljana. Thanks also go to drs. Adrijan Košir and Špela Goričan of the Ivan Rakovec Institute of Palaeontology of the Slovenian Academy of Sciences and Arts in Ljubljana for help with SEM images and their hospitality, and two anonymous reviewers who provided helpful comments.

\section{REFERENCES}

Belak, M., Koch, G., Grgasović, T., Vlahović, I., Velić, I., Sokač, B. \& Đ. Benček, 2005: Novi prinos stratigrafiji evaporitno-karbonatno-klastično-vulkanogenog kompleksa Komiškog zaljeva (otok Vis, Hrvatska).In: Velić, I., Vlahović, I. \& R. Biondić, (Eds.): Abstracts book of the $3^{\text {rd }}$ Croatian Geological Congress, Opatija 2005. Croatian Geological Survey, Zagreb, 13-14.

Borović, I., Marinčić, S., Majcen, Ž. \& N. Magaš, 1977: Osnovna geološka karta SFRJ 1:100.000, Tumač za listove Vis K 33-33, Jelsa K 33-34, Biševo K 3345.- Istitut za geološka istraživanja Zagreb, Savezni geološki zavod Beograd, $67 \mathrm{pp}$.

Bouma, A.H., 1969: Methods for the study of sedimentary structures.- John Wiley \& Sons, 1-458, New York.

Bukovac, J. \& D. Jamičić, 2009: Evaporitni kompleks (permotrijas).- In: Velić I. \& I. Vlahović, (Eds.): Tumač Geološke karte Republike Hrvatske 1:300.000 Hrvatski geološki institut, 26-27, Zagreb.

Buser, S., 1985: SFRJ 1:100.000, Tumač za listove Tolmin L 33-64 i Udine L 33-63- Geološki zavod Ljubljana Savezni geološki zavod Beograd, 103 pp.

Dickson, J.A.D., 1966: Carbonate identification and genesis as revealed by staining.- Journal of Sedimentary Petrology, 36, 491-505.

Evamy B.D. \& D.J. Sherman, 1962: The application of chemical staining techniques to the study of diagenesis in limestones.- Proc. Geol. Soc. London, 1599, $102 \mathrm{pp}$. London.

Ford T.D., 1991: Structures in limestones affecting the initiation of caves.- Symp. on the Origin and Development of Caves, The Transactions of the Cave Research Group of Great Britain, 13/2, 65-71.
Fornós, J.J., Gómez-Pujol, L., Cifre, L. \& F. Hierro, 2011: First Steps in Limestone Weathering and Erosion: An Atomic Force Microscopy (AFM) and Scanning Electron Microscopy (SEM) approach.- Acta Carsologica, 40/2, 275-282, Postojna.

Gams, I., 1959: Poskus s ploščicami v Podpeški jami.Naše jame, 12/2, 76-77.

Gams, I., 1985: Mednarodne primerjalne meritve površinske korozije s pomočjo standardnih apneniških tablet.- Razprave IV. reda SAZU: 361-386, Ljubljana.

Katz, A. \& G. M. Friedman, 1965: The preparation of stained acetate peels for the study of carbonates.- J. Sedim. Petrol., 35, 248-249.

Koch, G. \& M. Belak, 2003: Evaporitic-carbonate deposits of Komiža diapiric structure (Island of Vis, Croatia): their palynostratigraphy and sedimentological features.- $22^{\text {nd }}$ IAS Meeting of Sedimentology, Opatija 2003, Abstracts Book, 96, Zagreb.

Krklec, K., 2011: Corrosion of carbonate rocks and genesis of relief on Vis Island - correlation with selected coastal localities.- PhD thesis. Faculty of Science, University of Zagreb, pp 200.

Krklec, K., Lozić, S. \& A. Šiljeg, 2012a: Geomorfološke značajke otoka Visa.- Naše more, 5-6, 290-300.

Krklec, K., Lozić, S. \& D. Perica, 2012b: Neke značajke klime otoka Visa.- Naše more, 3-4, 148-160.

Liu, Z., Yuan, D. \& W. Dreybrodt, 2005: Comparative study of dissolution rate-determining mechanisms of limestone and dolomite.- Environmental Geology, 49, 274-279.

Marjanac T., 1986: Izrada i primjena acetatnih preparata. Sažeci predavanja 5. Skup sedimentologa Jugoslavije. Brioni 1986., 173-176, Zagreb.

Matsukura, Y. \& T. Hirose, 1999: Five year measurements of rock tablet weathering on a forested hillslope in a humid temperate region.- Engineering geology, 55, 69-76. 
Morse, J.W. \& R.S. Arvidson, 2002: The dissolution kinetics of major sedimentary carbonate minerals. Earth-Science Reviews, 58, 51-84.

Pahernik, M., 1998: Utjecaj klime i reljefa na intenzitet površinske korozije karbonata gorske skupine Velike Kapele. - Acta Geographica Croatica, 33, 4757.

Palenik, D., Korbar, T., Belak, M., Fuček, L., Matičec D. \& I. Vlahović, 2005: Strukturni sklop otoka Visa. In: Velić, I., Vlahović, I. \& R. Biondić, (Eds.): Abstracts book of the $3^{\text {rd }}$ Croatian Geological Congress, Opatija 2005. Croatian Geological Survey, Zagreb, 107-108.

Plan, L., 2005: Factors controlling carbonate dissolution rates quantified in a field test in the Austrian Alps.Geomorphology, 68, 201-212.
Prelovšek, M., 2009: Present day speleogenetic processes, factors and features in epiphreatic zone.- PhD thesis. University of Nova Gorica. pp 297.

Trudgill, S.T., 1975: Measurements of erosional weight loss of rock tablets.- British Geomorphological Research Group, Technical Bulletin, 17, 13-19.

Trudgill, S.T., 1977: Problems in the estimation of shortterm variations in limestone erosion processes.Earth Surface Processes, 2, 251-256.

Viles, H.A. \& C.A Moses, 1998: Experimental production of weathering nanomorphologies on carbonate stones.- Quaterly Journal of Engineering Geology, 31, 347-357. 